\title{
China's new role in the international financial architecture ${ }^{1}$
}

\author{
Peter DRYSDALEa, Adam TRIGGSa and Jiao WANGa,b \\ ${ }^{a}$ The Australian National University; bThe University of Melbourne. \\ Corresponding author: adam.triggs@anu.edu.au, 0401584 390, JG Crawford Building, \\ 132 Lennox Crossing, Acton ACT, Australia 0200
}

Keywords: China, international financial architecture, global governance, global
imbalances, global financial safety net, investment and trade

JEL Codes: F15, F43, F53, O19

\begin{abstract}
The rise of China is challenging the international financial architecture in a number of ways. This paper highlights three that are of critical importance: the challenge of absorbing massive Chinese savings; the incorporation of China into a cohesive global financial safety net; and the organisation of China's participation in funding the demand for international investment projects. The global financial architecture needs to be reformed. But what role should China play? The paper defines the options open to China and the opportunities and barriers it will face. We argue that China can work with the established economic powers in reforming the existing architecture. At the same time, China seeks cooperation in building new institutions and organisations that fill gaps in the existing arrangements. But no matter how international financial diplomacy plays out in the near term, deep financial and economic reform at home will alone deliver China a central role in the international financial architecture. Domestic reform could also attend to some of the challenges that currently plague China's impact on the system. The success or failure of these domestic reforms will be at the crux of the strength or fragility of the international financial architecture in the years ahead.
\end{abstract}

\section{Introduction}

The global economy and the global financial system are being shaped profoundly by the rise of China. China's rise has benefited the world immensely through substantial reductions in poverty, increased purchasing power and higher standards of living. But China's rise also poses challenges. It poses challenges not only for the global economy and global financial system but also for the institutions, forums and mechanisms that underpin them - collectively called 'the global financial architecture'. The global financial architecture includes the institutions and mechanisms that govern the global economy and the global financial system, the arrangements for providing international financial stability and emergency liquidity, and the international institutions for mobilising development finance.

Much of the global financial architecture was put in place decades ago and no longer reflects the composition of the global economy or the way in which it functions today. The paper details how the rise of China, together with that of other emerging economies,

\footnotetext{
${ }^{11}$ We are very grateful to the discussants, Chalongphob Sussangkarn and Masahiro Kawai, and participants in the APER workshop at which an earlier version of this paper was presented in Tokyo and to the editors of the journal, especially Colin McKenzie, Takatoshi Ito and Shujiro Urata, for their thoughtful comments and invaluable input to the development of the paper. We are also grateful to Sam Hardwick for his work on the final edit.
} 
challenges this architecture in three important ways. It challenges the global system's capacity to absorb the substantial increase in the supply of savings coming from China, with significant implications for global financial stability. It challenges the adequacy of the global financial safety net to incorporate China and the increase in financial integration and capital flows that have been associated with its rise. And it challenges the framework for investment financing, with China creating new institutions in response to the immense unmet demand for development finance.

The G20 and other international forums have moved to implement an agenda for reform of the global financial architecture which will help address these challenges. But progress is painstakingly slow. Faced with architectural inflexibility, the critical question is what role can China play in the current situation?

There are two options at the extreme. China could collaborate with the established powers in reforming the existing architecture or it could challenge the existing system by creating competing institutions and disengaging from the established regime. To date, China's approach has been mixed. It has worked collaboratively with the established powers in reforming institutions like the International Monetary Fund (IMF) and the World Bank. But in some areas China has created institutions which some argue directly compete with the existing system. The Asian Infrastructure Investment Bank (AIIB) is seen by some as one such example. Through this prism, China is seen as a challenger to the established global financial and economic order.

This paper argues that China has been effective in working collaboratively with the established powers in reforming the global financial architecture. At the same time, China has sought to create new institutions and organisations, to complement and fill gaps in the existing architecture. The paper examines the tension in these two roles. In this regard, the tensions emerging from China's creation of the AIIB are not dissimilar to the tensions that arose when Japan created the Asian Development Bank (ADB) in the 1960s.

But no matter how international financial diplomacy plays out in this area in the near term, the biggest impact on the architecture and on China's role within it will ultimately be through what reforms China succeeds in undertaking at home. China's domestic reform agenda - including financial reform, capital account liberalisation, and further internationalisation of the renminbi (RMB) - will profoundly shape the global financial architecture. China's reform agenda will help ameliorate the problem of global imbalances, particularly through more balanced patterns of saving. Successful reform will also deliver deeper and more integrated global capital markets, which will require a larger, differently structured and more cohesive global financial safety net. It will also mean more pressure on regional and global frameworks for investment.

The remainder of the paper is structured as follows. Section 2 explores the challenges that the rise of China has created for the global financial architecture. Section 3 looks at the reform agenda for the global financial architecture that has developed in the G20, the role China is playing, the role it can play, and the drivers and obstacles it will likely face. 
Section 4 looks at what impact China's own reforms will have on the global financial architecture and on China's role within it through the specific challenges identified in Section 2. Section 5 offers some concluding thoughts.

\section{China and the global financial architecture under strain}

The significance of China's rise is most apparent when we look at its growing share of the global economic system (see Figure 1). Measured in purchasing power parity (PPP) terms since 1980, China's share of world output has increased from 2 per cent to 17 per cent. Its share of world public and private investment has increased from 3 per cent to 30 per cent. Its share of world savings has increased from 3 per cent to 31 per cent. Its share in world trade (in US dollars) has increased from 1 per cent to 12 per cent. Its share of world public debt has increased from 3 per cent to 12 per cent. $^{2}$

\section{[INSERT FIGURE1]}

China's rise has brought immense benefits to the global economy. But it also poses a number of challenges, including for the global financial architecture. The three challenges explored in this section are that architecture's capacity to absorb Chinese savings, the global financial safety net's ability to incorporate China, and the organisation of China's participation in funding of the demand for international investment projects. It is important to note that China itself is by no means the whole story. In each of these challenges, advanced economies and other developing economies also play a critical and sometimes a leading role. What this paper aims to do is to identify the particular challenges and contributions associated with China.

\section{Absorbing Chinese savings into the global system}

The global challenge of absorbing China is seen acutely in the form of current account imbalances. China is an important contributor to these imbalances, which risk causing instability in the global financial system. China's contribution to current account imbalances stem from its high rates of savings relative to investment demand, driven in large part by distortions in the Chinese financial system and its economy.

The current account represents the difference between the level of savings and investment in an economy. China and other East Asian as well as European economies have large current account surpluses because they generate more savings than investment demand. The surplus of savings goes overseas and finances investment in economies which are in the opposite situation, with more investment demand than domestic savings. These economies, like the United States, United Kingdom, Canada and Australia, have current account deficits. Figure 2 shows the imbalance between the world's main surplus and deficit economies by showing each country's current account surplus or deficit as a percentage of world GDP.

\footnotetext{
${ }^{2}$ IMF World Economic Outlook Database, April 2016; WTO Trade Statistics 2015.
} 


\section{[INSERT FIGURE 2]}

The imbalance between surplus and deficit countries almost doubled between 2000 and 2006. The global financial crisis reduced these imbalances back to 2000 levels. But in the past two years they have increased once again, nearly to pre-crisis levels. Figure 3 shows the sum, over this timeframe, of the absolute values of current account surpluses and current account deficits as a per cent of world GDP.

\section{[INSERT FIGURE 3]}

Although it is by no means alone, China plays an important role in global current account imbalances. As a percentage of world GDP, China's current account surplus grew tenfold from 2000 to 2007. Although the Chinese surplus has since halved, it has grown rapidly since the crisis, equating to almost 60 per cent of the current account deficit of the United States (the largest contributor to the global current account imbalance).

These imbalances largely reflect efficient financial intermediation between countries, but they can also be problematic, especially for deficit countries. Growing deficits raise the risk of a "sudden stop": a change in sentiment where investors suddenly become unwilling to finance a country's deficit. International linkages and poor cross-border processes for the resolution of troubled banks and financial institutions mean that sudden stops can quickly become global events.

Economists, including Obstfeld and Rogoff (2009), Bernanke (2005) and King (2016), argue that the rise in global imbalances was intimately linked to, if not a key cause of, the global financial crisis, through fuelling unsustainable booms in credit and asset prices. Brad Sester (2016) from the Council on Foreign Relations warns that global imbalances are not only making a comeback, but are likely a key contributor to depressed global interest rates, with implications for long-run stability.

As Sester (2016) points out, the post-crisis growth of China's current account surplus has been the result of substantial domestic savings outstripping investment. ${ }^{3}$ The substantial stock of China's savings is not only a product of efficient intertemporal consumption shifting, but also the result of major economic, social and policy distortions. These distortions lead to higher precautionary savings by households due to a lack of social insurance and financial intermediation, and an accumulation of export surpluses in the corporate and government sectors promoted by China's export-oriented policy (Tao, 2012). In 2015, gross national savings in China were 48 per cent of GDP (Figure 4). The average for emerging market and developing economies is 32 per cent, and 21 per cent for advanced economies.

The increasing size of China's current account surplus contributes to global current account imbalances and potentially fuels instability. The global current account imbalance is an important way in which the global system is struggling to absorb the impact of

\footnotetext{
${ }^{3}$ According to Sester (2016), the driver of China's current account surplus used to be an undervalued currency boosting the trade balance.
} 
China's rise. Reforms that seek to remove these distortions will be crucial in helping to ease this burden. We will return to this point later.

\section{[INSERT FIGURE 4]}

\section{Challenges for the global financial safety net}

The global financial safety net refers to the set of international institutions, mechanisms and resources designated to help countries facing an economic or financial crisis. The safety net reduces global systemic risk by preventing crises from spreading across borders. The safety net consists of global components like the IMF, regional components like the European Stability Mechanism and the Chiang Mai Initiative Multilateralization, bilateral components like currency swap lines and perhaps a unilateral components in the form of foreign exchange reserves.

China's impact on the safety net has been two-fold. First, it has increased the size of the safety net through its support of global institutions (it has provided bilateral loans to the IMF to increase its funding base) as well as regional institutions (such as the Chiang Mai Initiative Multilateralization). China has also been a leader in creating new regional institutions (such as the BRICS currency reserve pool) and has been proactive in creating new bilateral support through a network of currency swap lines with 30 different countries. And in the domestic sphere, it has created unilateral supports through its accumulation of foreign exchange reserves.

While China has increased the size of the safety net, it has also challenged the safety net in three important ways. First, China's rise has resulted in a situation where its voting power in the safety net's most important institution - the IMF - is substantially lower than its importance in the global economy. This has put pressure on the IMF to be reformed so as to strengthen not only its legitimacy but also its permanent funding. Yet the IMF has proved rather resilient to reform. The United States Congress took over five years to pass the reforms agreed by the G20 in 2010. These reforms only marginally increased China's representation in the IMF relative to its share of the global economy and many of them remain unimplemented. ${ }^{4}$

Second, China's support of regional, bilateral and unilateral institutions and mechanisms has made the safety net more fragmented, reducing its coverage, responsiveness and predictability. These costs are discussed below. China's support of these regional mechanisms has in part been due to the difficulty of reforming the IMF. Though not alone in this regard, China has been more active than most in its support of these alternatives, particularly through regional initiatives like the BRICS currency reserve pool, its network of currency swap lines and its holdings of foreign exchange reserves.

Third, the sheer size of the Chinese economy necessitates a larger safety net. China's foreign exchange reserves are larger than its short-term financing requirements. Given

\footnotetext{
4 The commitment to vacate more seats on the Executive Board for emerging market economies, for
} example, is yet to be implemented. 


\section{[INSERT FIGURE 5]}

substantial domestic buffers, ample fiscal space and the various instruments at its disposal it is unlikely China would need to use the safety net in the near-term. But the rise of China has been associated with a deepening of regional and global integration in trade and finance. Through increased capital flows, larger external financing requirements and elevated transmission of shocks, a larger safety net is required. In light of these developments, the safety net in its current form is insufficient. This has been the finding of analysis from the IMF (2016), the Bank of England (Denbee et al, 2016) and the Australian Treasury (Hawkins et al, 2014).

The safety net's insufficiencies can be illustrated as follows. The size of the safety net can be measured by adding together the resources in its global ${ }^{5}$, regional ${ }^{6}$ and bilateral ${ }^{7}$ components (see footnotes for the institutions and mechanisms that are included in this analysis). Although analysts sometimes disagree on what should be included in the safety net, this paper takes a conservative approach by including as many institutions as possible to see if the safety net is large enough when estimated generously.

The results are set out in Figure 5. Adding up the safety net's global, regional and bilateral components the safety net totals US $\$ 4.6$ trillion. If we only take account of financial resources that are immediately available (which means resources that are paid-in and not pre-committed to existing programs), the estimate of the size of the safety net falls to around US\$2.7 trillion. ${ }^{8}$

Even on this generous estimate the safety net is not likely to be adequate to cope with a major financial crisis. The IMF considers the growth in global capital flows to be a reasonable benchmark for assessing how much the safety net should grow by over time. This is because capital flows reflect the potential financing short-fall that a country might face in a financial crisis (see IMF, 2011 and Lagarde, 2016). Using this metric, since 1980 the size of the safety net has grown 12-fold while global capital flows have grown more

\footnotetext{
${ }^{5}$ Globally the safety net consists predominantly of resources mobilised through the IMF but also potentially the World Bank and the Bank for International Settlements, which have both provided resources into the safety net at different times in the past (see Montiel, 2014 and Lustig, 1995).

${ }^{6}$ Regionally the safety net consists of regional financing arrangements (RFAs) and development banks which historically have both provided support during crises. The main RFAs used in this paper's calculations are the Arab Monetary Fund, the Latin American Reserve Fund, the North America Framework Agreement, the EU's Balance of Payments Assistance Facility, the European Stability Mechanism, the Chiang Mai Initiative Multilateralization and the BRICS currency pool. The main development banks used in this analysis are the ADB, the Inter-American Development Bank, the Development Bank of Latin America, the African Development Bank, the Asian Infrastructure Investment Bank, the New Development Bank and the Islamic Development Bank.

${ }^{7}$ Bilaterally the safety net consists of currency swap lines from China (outside of the Chiang Mai Initiative Multilateralization) and those from the United States and the European Central Bank during the global financial crisis (as a proxy for what might be expected from those central banks in a time of crisis). To provide a measurable number, the unlimited swap lines from the US Federal Reserve are back-dated to their size before they became unlimited.

${ }^{8}$ This finding is similar to that of Hawkins et al (2014), the IMF (2011) and the IMF (2016). Hawkins et al (2014) find the safety net is around US $\$ 2.7$ trillion, similar to the finding of the IMF (2011). The more comprehensive IMF (2016) study suggested it was closer to US\$3.7 trillion after accounting for more RFAs.
} 


\section{[INSERT FIGURE 6]}

than 25-fold. As a result, the IMF has warned that the size of the safety net has not kept pace with the growth in capital flows (see Lagarde, 2016). The IMF's analysis in 2016 found the safety net to be around US $\$ 3.7$ trillion in size but warned this was unlikely to be sufficient in the face of a widespread shock. Staff at the Bank of England (Denbee et al, 2016) raised similar concerns. Running a series of stress scenarios through partialequilibrium models they find that the safety net is insufficient in the most severe crises.

Figure 6 compares the size of the safety net in 1980 to 2015 and shows that its growth has primarily come from the growth in regional financing arrangements (RFAs) and currency swap lines. Foreign exchange reserves have also grown substantially from US $\$ 1.3$ trillion in 1995 to US $\$ 12$ trillion by end-2013 (IMF, 2016).

Another critical issue is that the safety net has become more fragmented. Fragmentation of the safety net poses questions about the safety net's speed, coverage, predictability and consistency in responding to crises. It means that the coverage of the safety net is patchy, leaving some countries more exposed to systemic risks. The IMF (2016) found that while the safety net serves reserve-currency advanced economies well, non-systemic emerging market and developing economies are served poorly. Denbee et al (2016) warn that the safety net is increasingly fragmented and that its different components are not necessarily substitutable, noting that its coverage is patchy, and while swap lines and RFAs can play an important role in the safety net they are not a substitute for a strong, well-resourced IMF. Figure 7 illustrates this patchy coverage by showing the size of the safety net, this time including foreign exchange reserves, from the perspective of each G20 country.

Fragmentation means that the safety net is less predictable and consistent. Truman (2013) showed this by comparing the institutional response and conditionality approach to the Asian financial crisis to that of the European debt crisis. ${ }^{9}$ Fragmentation also means the safety net is becoming increasingly decoupled from the IMF and reliant on weaker alternatives. The Chiang Mai Initiative Multilateralization (CMIM) is an example of this decoupling. ${ }^{10}$ Regional arrangements like the CMIM are also largely untested and make imposing conditionality on neighbouring countries politically difficult. Their resource base is far narrower than global institutions, the cost of raising capital is greater, ${ }^{11}$ moral hazard is more perverse and their surveillance is less effective (see Sterland, 2013).

\footnotetext{
${ }^{9} \mathrm{He}$ found that conditionality was less strenuous and financing more generous in the latter than the former. Truman suggests a key reason for this was the IMF's minority lender status alongside the European Stability Mechanism in the European debt crisis.

${ }^{10}$ The CMIM has gradually raised the IMF-delinked portion to 30 per cent, meaning members can draw up to 30 per cent of their maximum borrowing amount without requiring IMF lending conditions. ASEAN is now considering raising this to 40 per cent (see Pitakdumrongkit, 2015 for a discussion).

${ }^{11}$ Issuing high-yielding local currency debt to purchase foreign exchange reserves is a costly exercise which, according to the Bank of England, results in an annual cost to emerging economies of around 0.5 per cent of GDP (Bank of England, 2015).
} 


\section{[INSERT FIGURE 7]}

\section{Challenges in international development financing}

The rise of China and other developing economies has challenged the framework for financing international investment projects. Not only do these economies have substantial demand for financing for investment, they are also creating new investment institutions and agreements which complicate the global framework and potentially compete with it.

China is the primary element of this challenge. China and other Asian countries have substantial demands for investment financing. Asia's infrastructure deficit alone is estimated at US $\$ 8$ trillion from 2010 to 2020, more than 60 times the amount given annually in development assistance (ADB, 2013). Funding through existing institutions like the World Bank and the ADB, small relative to the size of demand, has shrunk in recent years. There is scope for intermediating Asian savings to cope with the region's huge shortfall in infrastructure investment.

China has responded to this challenge through a range of bilateral initiatives, the creation of new regional institutions (most notably the AIIB and the New Development Bank) and through regional agreements in the form of the Belt $\&$ Road initiative.

As with the discussion of the financial safety net above, China's efforts in this area have provided much-needed resources. But its efforts also carry potential economic and strategic costs. Many commentators, particularly in the popular media, have characterised the creation of new institutions like the AIIB and the New Development Bank as vehicles for China to advance its own unilateral strategic objectives in Asia at the expense of the United States. Callaghan and Hubbard (2016) document these concerns in detail. ${ }^{12}$

How justifiable are these concerns? The AIIB is an important vehicle for delivering $\mathrm{Xi}$ Jinping's signature foreign economic policy initiative - the Belt \& Road initiative focused on better integrating markets within Asia and Europe. While the Belt \& Road initiative undoubtedly serves national strategic goals for China, the goals of greater integration and infrastructure investment are also shared with many other countries in the region. Both APEC and ASEAN have been promoting a similar agenda - known as 'connectivity' - for many years now (Callaghan and Hubbard, 2016). Ironically, many of the concerns expressed about the AIIB are the same concerns that were expressed when Japan moved to establish the ADB in the $1960 \mathrm{~s}^{13}$. The ADB is now widely recognised as being an important institution which fills a critical gap in the Asian region (Drysdale, 2014).

\footnotetext{
${ }^{12}$ See 'China uses Global Crisis to Assert its Influence,' Washington Post, April 23, 2009; 'AIIB: America's Influence in the Balance,' The Straits Times, October 29, 2014; 'US Warns of Credibility Threat,' Financial Times, March 17, 2015; 'Beijing Eyes Closer Ties,' The Korea Herald, July 3, 2014; 'With One Eye on Washington,' Reuters News, July 3, 2014; 'Buying Countries for Influence,' Korea JoongAng Daily, May 12, 2014; 'China Trounces U.S.', Wall Street Journal, March 20, 2015.

13 The United States initially opposed the ADB initiative.
} 
There is a risk, however, that China might prevent the AIIB from becoming a genuine multilateral development bank. China has a larger veto power over decisions in the AIIB than the major shareholders have in other multilateral banks like the ADB and World Bank. The biggest risk to the bank is China's instinct to retain control over all significant Chinese institutions. While it is still early days, there is little evidence that China is seeking to prevent the AIIB from becoming a genuine multilateral development bank but should that happen, however, it would cause greater fragmentation in the architecture.

\section{China's role in reforming the global financial architecture}

The rise of China calls for urgent change in the international financial architecture. In this section, we first identify a number of major drivers of change and the obstacles that stand in its way. We then examine the role that China has been playing and what role it might play to reform the international financial system, given the competing forces pushing forward and drawing back reform in the face of change.

\section{Drivers and obstacles to change}

The ascendancy of the emerging powers and the need to represent their interests in the existing system is the first and primary driver of change. As discussed earlier, the global financial architecture that we have today was first established in the mid-1940s, featuring a US-dominated international rules and order, the US dollar as the cornerstone of international monetary system and the IMF responsible for maintaining the international financial stability and acting as a lender of last resort.

This system functioned well for more than half a century, facilitating economic openness and strong economic growth. It has maintained financial stability until emerging market economies countries started their dramatic catch-up to the established industrial powers. The emerging powers have a natural interest in participating more in the international decision-making process and being represented in international organizations, especially the IMF. This has motivated reform and restructuring of the global financial system, importantly reform of the IMF.

Another important driver of change to the global financial architecture is the inefficiency of the current international reserve system, as evidenced in the experience of the global financial crisis and prolonged stagnation in the post-crisis period. The sub-prime crisis originated in the United States but had worldwide contagion effects. The emerging market economies and developing countries have been anxious about the negative spillovers on their domestic economies of the unconventional monetary easing conducted in industrial countries in the aftermath of the crisis. Making the financial system more resilient and more effectively coordinated is an interest shared by the industrial powers and emerging countries alike.

The third factor that energizes restructuring of the current system is the China factor itself. Developing countries have been calling for changes to the global financial 
architecture since the mid-1990s when a number of emerging economies experienced financial crisis. ${ }^{14}$ Not until China's participation did the restructuring of the system gain momentum. China clearly has the capacity and the will to be a strong voice in actively pushing the reform and restructuring of the current system.

The G20 has developed a broad agenda for global governance reform. Reform of the IMF and World Bank has been a central part of this agenda, with efforts focused on ensuring that the governance and funding of these institutions better reflects the global economy of the 21 st century. The G20 has also focused on increasing the size of the global financial safety net and improving cooperation between its different components. It has developed a work program on global energy governance reform. It has established a Trade Working Group to explore how to strengthen the global trading system and produce better cohesion between its different layers. It has created the Financial Stability Board and has strengthened the surveillance activities of the IMF.

While the G20's global governance reform agenda is substantial, progress has been painstakingly slow. There are two major constraints that impede the evolution of the international financial system. The first has to do with politics. Political resistance in the United States and elsewhere has delayed reform. For example, as noted earlier the IMF reform package was agreed at the G20 summit in Seoul in 2010. The Obama administration was supposed to implement it promptly. In mid-January 2014, the US Congress refused to approve the IMF reform legislation, which brought to a halt the slow progress of the IMF reform, and the Obama administration deserves much of the criticism (Truman 2014). The reform was subsequently approved but only two years later. This political difficulty in pushing reform forward has brought into question the representativeness and legitimacy of the IMF as the principal vehicle for maintaining international financial stability. Now that the first-round reforms are in place, there is need to take the next round forward quickly, as few of the areas in the agenda have made much progress in recent years.

Another impediment to efficient transformation of the financial architecture is the tension between established and emerging powers. This is natural as rising powers, like China, disturb the established order and their intentions attract suspicion. The Belt \& Road initiative, for example, has been interpreted by some as a Chinese move to build a competing global system and seek hegemony, even though Chinese leaders have made it clear that China has no intention of abandoning the current global system (Huang, 2016). ${ }^{15}$

\footnotetext{
${ }^{14}$ Mexico experienced a severe financial crisis in 1994-95; Indonesia, Thailand, and South Korea suffered the most from the Asian Crisis in 1997-98. Russia and Brazil confronted similar turmoil in 1998 and 1999. 15 The communication and adjustment of intentions is an important means on overcoming resistance to change. The G20 is a critical platform through which to resolve these issues.
} 


\section{China's participation in the reform of global financial architecture}

With the global financial architecture proving to be inflexible to change and to accommodating new systemically important players, what role is China able to play and what role should it play?

Conceptually, there are at least three possible approaches China could take in reforming the global financial architecture. The first approach is to work with the established powers to push forward reform of the global financial architecture outlined above. China has already assumed greater responsibilities in the global financial architecture and has been actively involved in the agenda of reforming major institutions such as the IMF.

China has taken a seat in the world's pre-eminent forum for economic decision making, the G20, a major agent in the reform of the IMF. China chaired the summit in 2016. It continues to work on strengthening global macroeconomic cooperation and reforming the international monetary system with other G20 member countries.

China was one of the strongest advocates for reforming IMF voting rights and quota allocations to better represent the composition of the world economy. It agreed to increase its contribution to the IMF by expanding the latter's emergency funds in order to get agreement to the quota and governance reform during the G20 summit in 2010. The 14th General Review of Quotas at the IMF, which became effective on January 26, 2016, delivers a 100 per cent increase in total quotas and a major realignment of quota shares from the advanced European countries and Gulf States to emerging nations. China became the third largest member country in the IMF, and there are now four Emerging Market and Developing Countries (Brazil, China, India and Russia) among the 10 largest shareholders in the Fund.

An alternative approach for China is to create new institutions and organisations, more representative of the emerging powers and developing countries, which the existing system fails to provide. While China and other emerging economies welcome the restructuring of the existing global financial architecture to better reflect their growing importance, actual reform generally proceeds at a very slow pace, much slower than the pace at which the world economy is transforming from a system dominated by advanced economies into a multipolar system.

The primary example of the second approach is the establishment of the AIIB and the Belt \& Road initiative. ${ }^{16}$ The US Congress's delay in ratifying the quota IMF revision and reluctance to reform the governance structure of the other international financial institutions all lent support to the logic that China should push ahead in establishing the AIIB. The primary task of the AIIB, according to Chinese President Xi Jinping, is to provide capital for the Belt \& Road initiative (Xinhua, 2015) while the latter is ostensibly

\footnotetext{
${ }^{16}$ Chinese President Xi Jinping proposed a Silk Road economic belt on a visit to Kazakhstan in September 2013, and a 21st-century maritime Silk Road in Indonesia the following month, simultaneously with the AIIB proposal. These two proposals form the so-called 'Belt \& Road initiative'.
} 
designed to serve as a new regional cooperation model to promote greater economic and financial cooperation within the Belt \& Road region and with industrial countries through a series of infrastructure projects, financial support, unimpeded trade and human capital exchange (Huang, 2016).

The AIIB and the Belt \& Road initiative are China's own contributions to the global financial architecture, based on more than 30 years of reform and development experience. The AIIB is also the first international organisation established by a developing country with its headquarters residing in Beijing and the top official being Chinese. It is too early to make a definitive judgment as to the success or failure of the cross-border projects funded by the AIIB or of the Belt \& Road initiative. It is clear, however, that China is gradually taking on greater responsibility in global economic and financial issues in a way that a responsible emerging economic power might be presumed to. China is exploring the avenues through which it can make its own contribution to the global economy that benefits itself as well as its developing and developed country partners.

China has also supported the creation of the BRICS currency reserve pool, the CMIM and the New Development Bank. It works collaboratively on regional economic issues within APEC, ASEAN +6 and the East Asia Summit. While noting some of the challenges discussed earlier, all of these institutions are now important aspects of the global financial architecture and represent important contributions by China.

\section{China as a responsible global stakeholder}

The third approach — which might be the most appropriate course for China in lending its weight to global financial architecture reform - is to focus specifically on developing a two-tiered global financial safety net centred on a representative IMF and with strong cooperation among major economic players. This involves a combination of both the approaches discussed above, namely, pushing forward the reform and restructuring of the IMF to make the existing system more representative and more efficient while at the same time establishing new institutions such as the AIIB and the Belt \& Road initiative to build on and complement the existing system with emphasis on regional cooperation among emerging powers.

China's pursuit of this third approach raises questions about China's intentions. As discussed earlier, the establishment of the AIIB and the Belt \& Road initiative are not automatically welcomed as a Chinese contribution to strengthening the current financial system, but are seen by some rather as a challenge to it. The existing global financial architecture has clearly benefited China greatly over the more than three decades of opening up through embracing market-based rules and norms promoting free trade, free investment and free flows of capital. Policy advice from the IMF, even if it has not always been fully adopted, has helped China avoid some major policy mistakes (Yi, 2011). It is in China's own interests to stay within the existing system, rather than try to establish an alternative system. China, as a representative of the emerging powers, has a responsibility 
to work with other economic powers in the G20 and through the global institutions to help shape the rules and norms of the global governance into the future. (Huang, Dang and Wang, 2011).

\section{The impact of China's domestic reform agenda}

No matter how international financial diplomacy plays out in the near term, deep financial and economic reform at home will alone deliver China a central role in the international financial architecture. It will also have significant implications for the challenges that currently plague the global financial architecture. The success or failure of Chinese domestic reforms is at the crux of the strength or fragility of the international financial architecture in the years ahead.

China's latest (13th) Five Year Plan (2016-2020) emphasises three critical reform priorities: (1) the further transition of economic development from investment to consumption and services by improving investment efficiency; (2) raising living standards for the poor, improving environmental protection and innovation, and upgrading information technology; and (3) deeper marketization of a wider range of factors and products, in particular through financial liberalisation.

Financial liberalisation is at the centre of China's reform agenda. Its core elements include interest rate deregulation, a flexible exchange rate, lower barriers to market entry, strengthened regulatory framework and infrastructure and capital account liberalisation (Overholt et al, 2016). Financial reform, combined with capital account liberalisation, will facilitate the integration of the Chinese financial system with regional and global capital markets so that savings, investment and risks can be mediated globally, expanding the frontiers of production, investment and consumption. The internationalisation of the RMB is a related process that will enable interest-rate and exchange-rate flexibility to help manage economic shocks arising from sudden shifts in capital flows (Overholt et al, 2016).

The implications of these reforms for international financial architecture are significant, particularly when considered in the context of the challenges discussed in Section 2. Rebalancing the Chinese economy will increase domestic consumption, grow the middle class and domestic demand, and make China an even more substantial market for the world's exports. This will help rebalance global trade and further increase China's importance in the global trading system.

Strengthening the social safety net in China and improving access to financial services like insurance and fund management will help reduce China's precautionary savings, playing an important role in reducing China's contribution to global current account imbalances. Using a structural model of savings decisions, Choi, Lugauer and Mark (2014) find that more than 80 per cent of China's household savings arise from a precautionary motive. This confirms the view of the IMF's Chamon, Liu, and Prasad (2010) who find that income uncertainty explains much of the increased savings among Chinese households 
and that China's strong average income growth has been accompanied by a substantial increase in income uncertainty. Further reform of state-owned enterprises will likely also help in reducing China's high rates of savings (Hoffman and Kuijs, 2006).

China's reforms will have critical implications for the safety net. On one hand, China's reforms, by making the Chinese economy and financial system deeper and more resilient, will likely reduce the tail-risk of a shock emanating from the Chinese economy that could hurt innocent bystander countries. Although there is also the risk that Chinese reforms go badly, which could in turn generate such a shock, the gradual pace under which the reforms are being undertaken suggests this risk is not high (see Overholt et al, 2016).

On the other hand, China's reforms will exacerbate the forces that necessitate a larger safety net in the first place. Capital account liberalisation and financial integration will mean deeper and more integrated global capital markets. This will increase the volume of capital flows and require a larger safety net. The slow pace of IMF reform may well imply a greater reliance on larger RFAs, a greater prevalence of currency swap lines and a continued accumulation of foreign exchange reserves. This, as noted above, is leading to a safety net that is patchy in its coverage, less consistent, less predictable and more costly. In all these respects, China's reform agenda will pose opportunities and challenges for the safety net.

Financial reform and capital account liberalisation will also mean greater opportunities for Chinese investment abroad and for foreign investment in China. This will test the domestic foreign investment regimes in many countries, including China. It will put further strain on the existing patchwork of bilateral, regional and multilateral rules regarding investment, and elevate the negotiation of international investment agreements as a top policy priority. In light of growing Chinese investment, China will have an important role to play in negotiating the evolving international rules around foreign investment.

\section{Conclusion}

The global financial architecture has been challenged by the rise of China and other emerging economies. This paper has focused on how the global system can absorb the growth of the Chinese economy and financial system, and what needs to change to cope with risks that derive from the new structure of the global economy. Many of the institutions, forums and mechanisms that underpin global financial architecture were created decades ago and their structure no longer reflects circumstances in the global economy.

The paper highlighted three critical challenges to the architecture posed by China's rise. First, the global system has struggled to absorb substantial Chinese savings in a sustainable way, evidenced by large current account imbalances with implications for global financial stability. Second, the global financial safety net, particularly the IMF, has struggled to accommodate China. China has contributed substantially to a larger safety 
net but this has been at the cost of increased fragmentation through China's support for regional, bilateral and unilateral alternatives to the IMF. China's rise has also meant a larger burden on the safety net. There are now more systemically important countries for the safety net to cover and capital markets that are deeper and more integrated than ever. Finally, China has contributed much to the global framework for investment financing through increased funding and new institutions and mechanisms. But these have also posed challenges, with some questioning whether these institutions and mechanisms compete with or complement the existing framework.

In light of these challenges, what role must China play in global reform? The paper argued that in international economic diplomacy China needs both to work with the established economic powers in reform of the established institutions at the same time as it seeks support for building new institutions and organisations that fill important gaps in the existing architecture.

More important than its international diplomacy, however, will be what reforms China succeeds in undertaking domestically. Deep reform of the Chinese financial market and effective capital account liberalisation will deliver to China and its currency a key role in the international financial system and attend to many of the problems that currently plague that system. China's reforms will boost domestic demand, making China an even more important market for international exports. Reforms to boost the social safety net and increase access to insurance and fund management services will help reduce precautionary savings and, through this, China's contribution to global current account imbalances.

China's reforms, particularly capital account liberalisation, will also mean deeper financial integration, putting further strain on an already inadequate global financial safety net. China's reforms also will mean more investment opportunities for Chinese people abroad and for foreigners within China. This will test the global patchwork of rules on investment, as well as the domestic foreign investment regimes within countries.

The most important of these changes are within China's hands and do not require attendance by other powers big or small. China's success or failure in these reforms will be at the crux of the strength or fragility of international architecture in the years ahead, so other major players have as much interest in cooperation with China in the delivery of its reform agenda as China does in reforming the global financial architecture. 
Figure 1: China's growing share of the world economy and world financial system (per cent) China's share of world GDP, investment, savings and debt (in PPP) and trade (in USD)

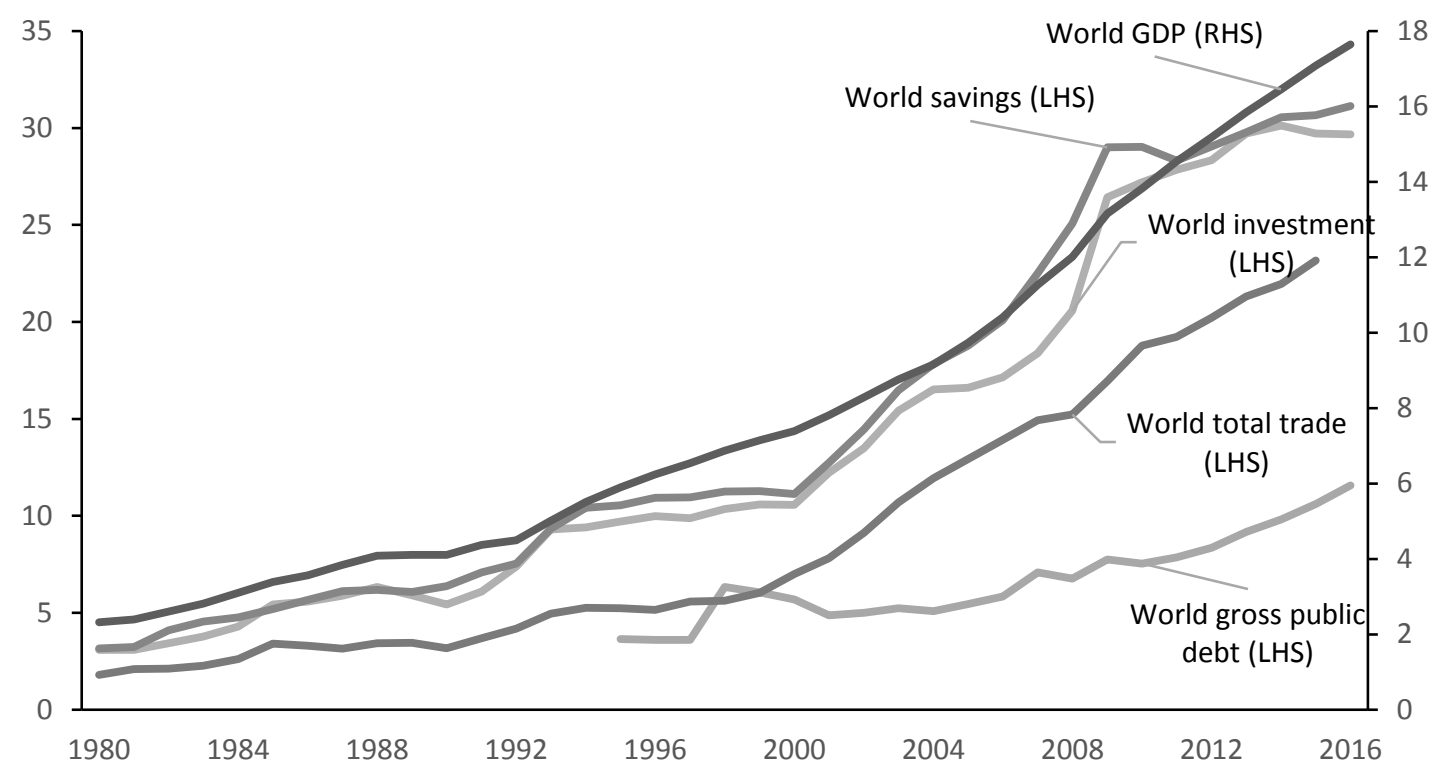

Sources: IMF World Economic Outlook Database, April 2016; World Trade Organisation (WTO) Trade Statistics 2015.

Figure 2: Global current account imbalances: Current account surplus and deficits as a per cent of world GDP in 2016

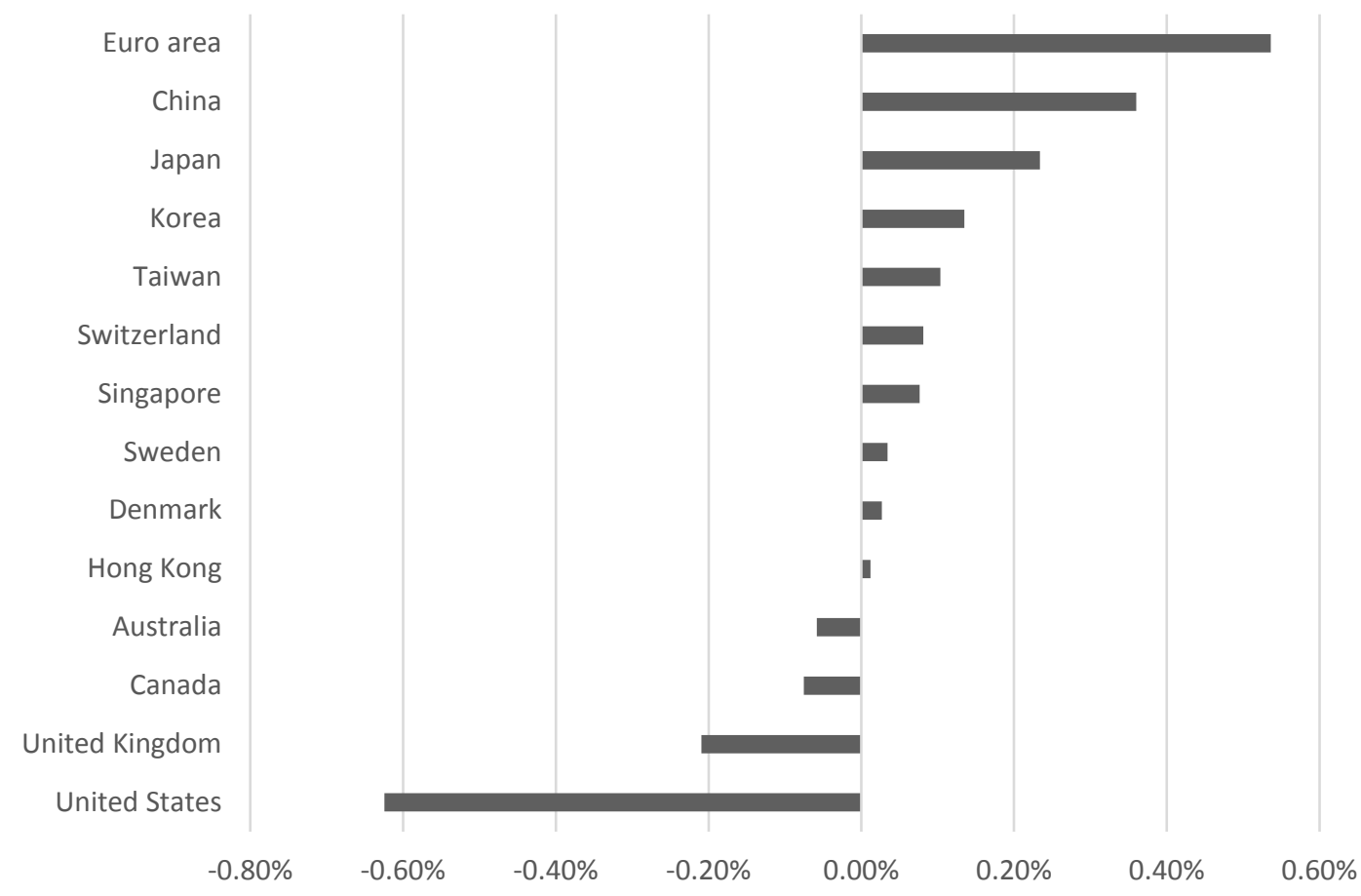

Source: Data from the IMF World Economic Outlook database, October 2016 
Figure 3: The sum of the absolute values of current account surpluses and deficits (as a per cent of world GDP) from 2000 to 2016

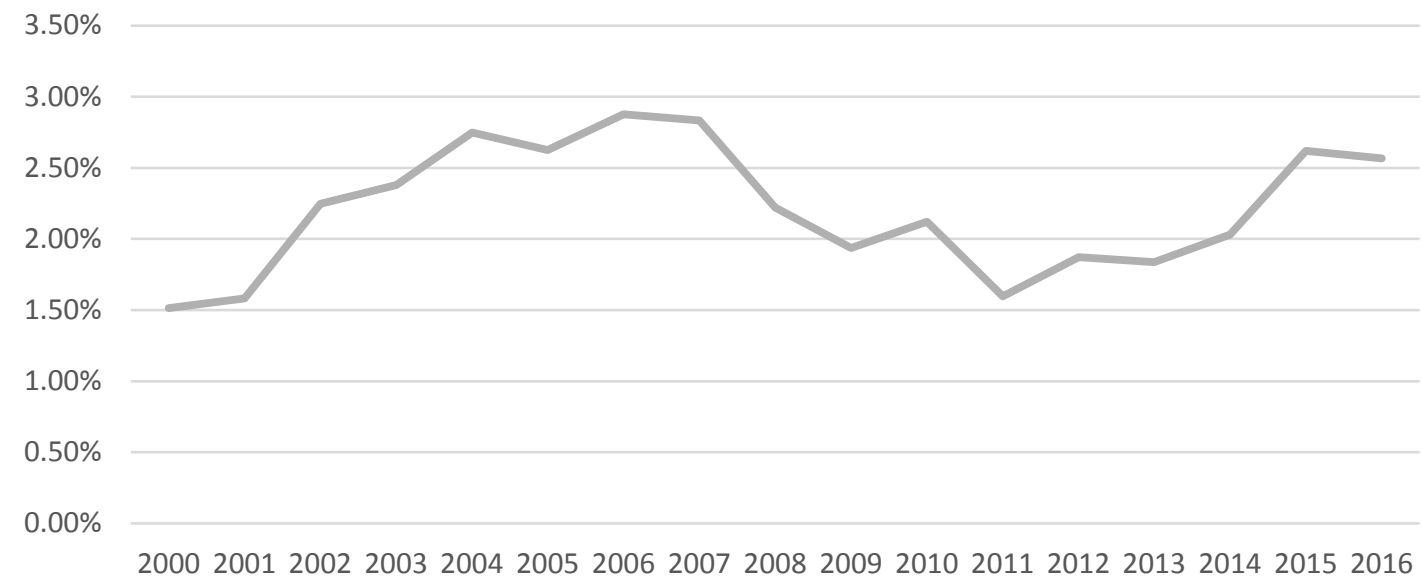

Source: Data from the IMF World Economic Outlook database, October 2016

Figure 4: Gross national savings as a per cent of GDP in 2000 and 2016

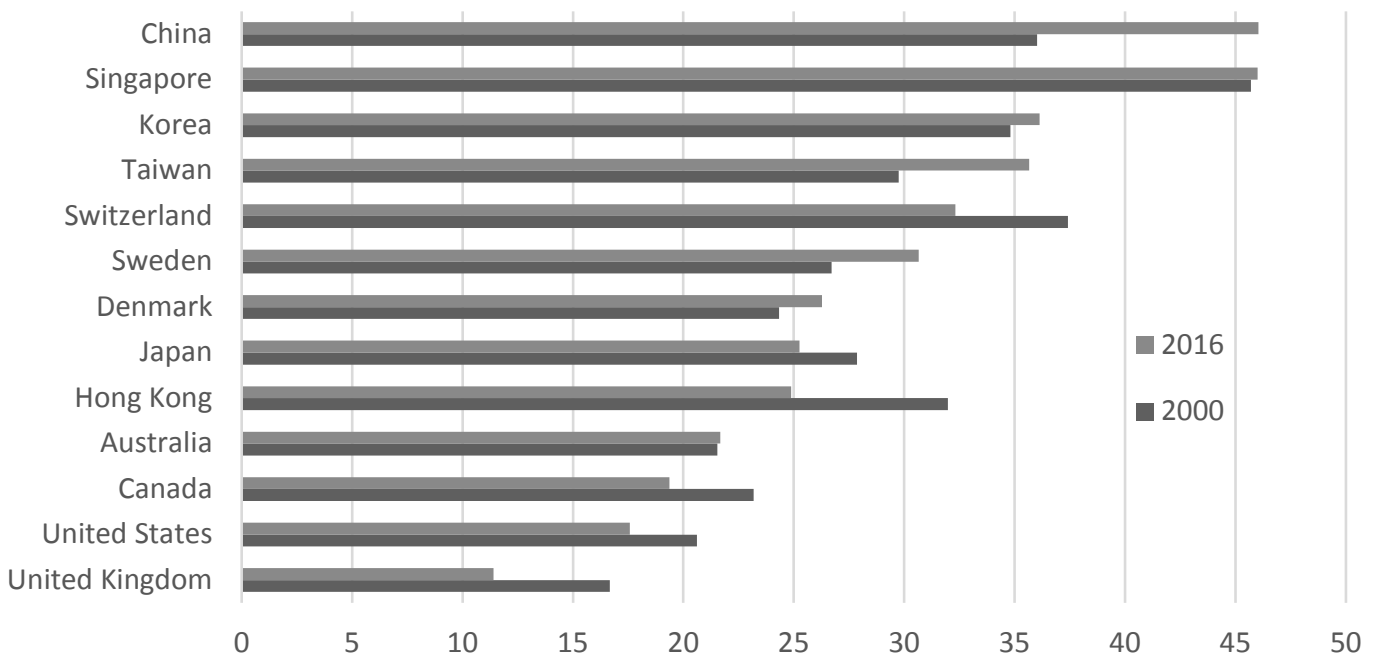

Source: Data from the IMF World Economic Outlook database, October 2016 
Figure 5: Total safety net resources compared to available resources

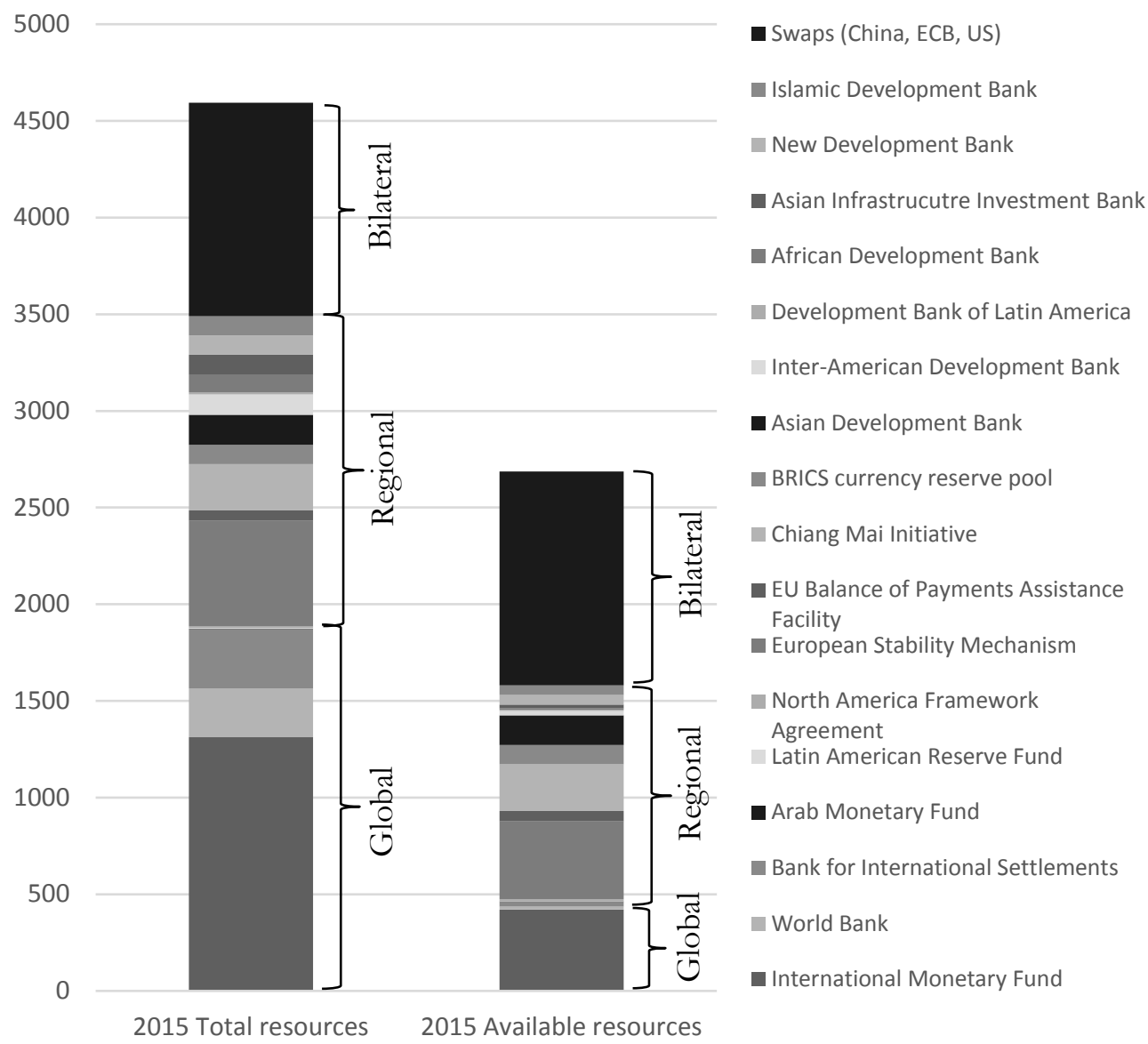

Source: Data from annual reports of each institution in 2015 
Figure 6: The global financial safety net from 1980 to 2015

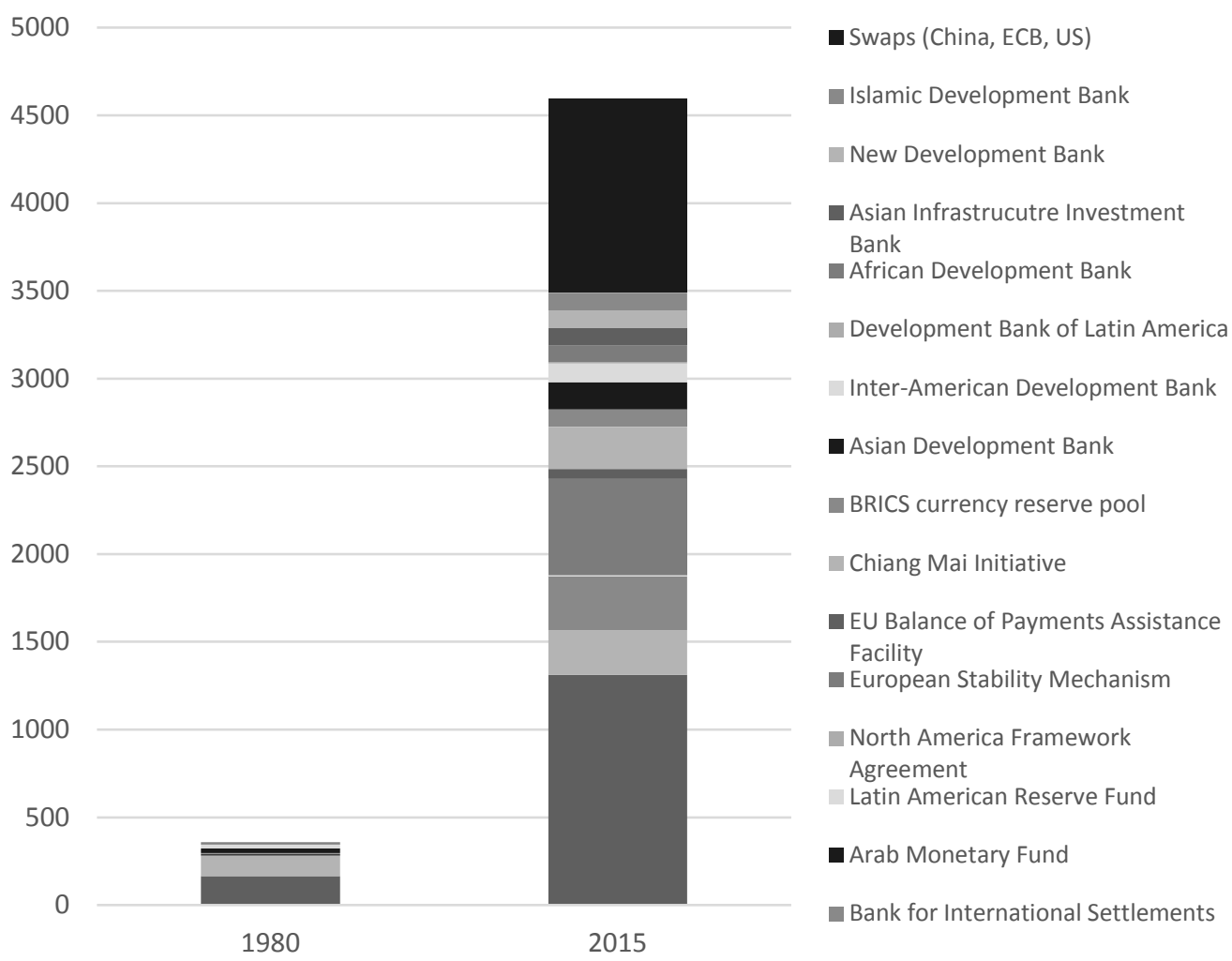

Source: Data from Annual reports of each institution in 1980 and 2015

Figure 7: The safety net from the perspective of individual G20 countries

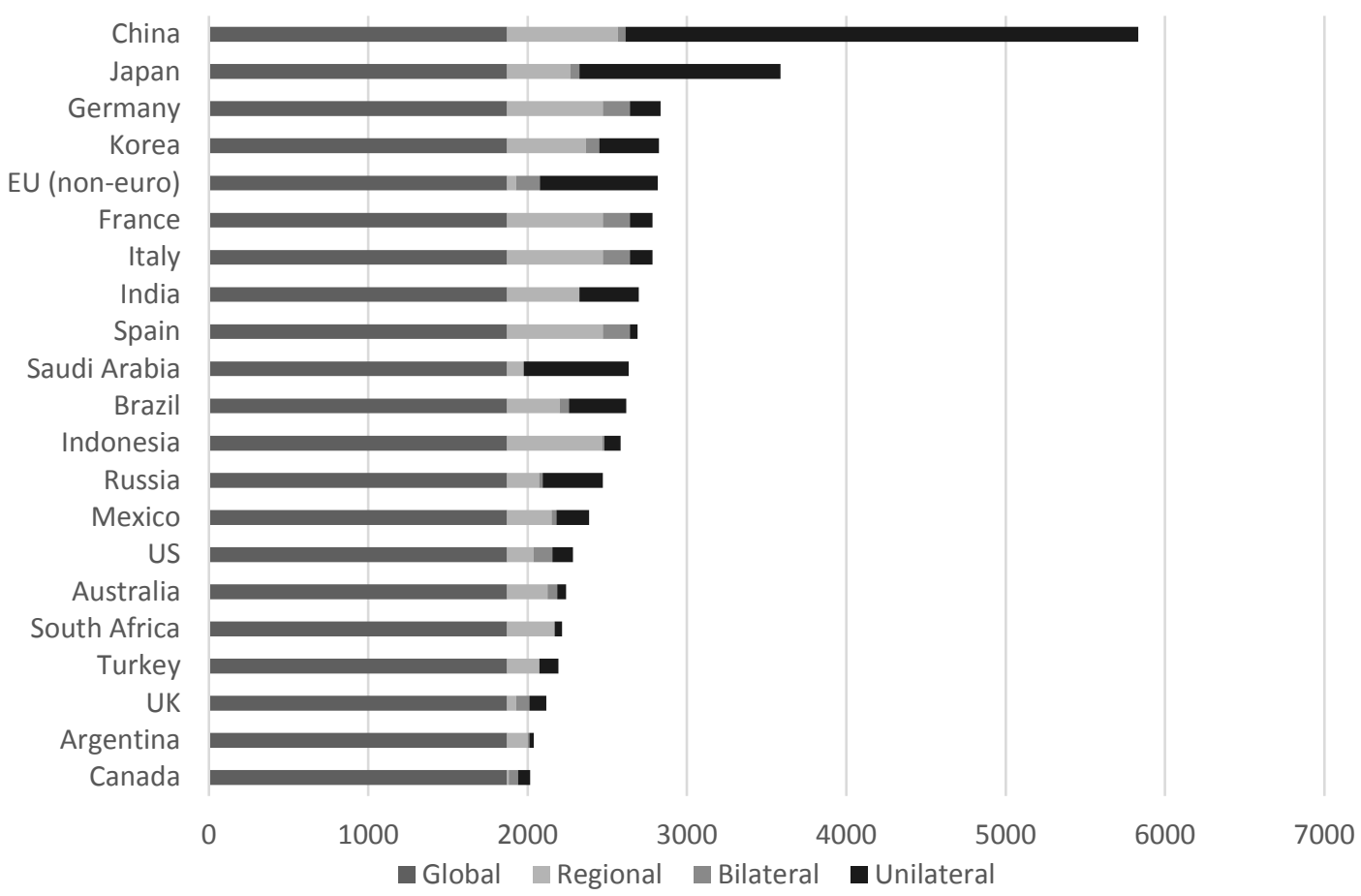

Source: Based on each country's membership of the international and regional organisations listed in Figure 6 and the size of any swap lines that country had from 2007 to 2015 with the US, Europe and China. 


\section{References}

Asian Development Bank (2013). Infrastructure for a seamless Asia. Asian Development Bank and Asian Development Bank Institute.

Bank of England (2015). Fixing the global financial safety net: Lessons from central banking. Minouche Shafik, VOX CEPR's Policy Portal, 5 October.

Bernanke B. (2005). The Global Saving Glut and the U.S. Current Account Deficit. Sandridge Lecture, Virginia Association of Economists, Richmond, Virginia, 10 March.

Blanchard O. and Milesi-Ferretti G.M. (2011). (Why) Should currency account balances be reduced? IMF staff discussion note, SDN/11/03, 1 March.

Callaghan M. and Hubbard P. (2016). The Asian Infrastructure Investment Bank: Multilateralism on the Silk Road. EABER Working Paper Series, Paper No. 116, 15 January.

Chamon M., Liu K. and Prasad E. (2010). Income uncertainty and household savings in China. IMF Working Paper, WP/10/289.

Choi H., Lugauer S. and Mark N.C. (2014). Precautionary savings of Chinese and US households. NBER Working Paper No. 20527.

Council on Foreign Relations (2015). The spread of central bank currency swap lines since the financial crisis. Council on Foreign Relations, March. Available at: https://www.cfr.org/international-finance/central-bank-currency-swaps-since-financialcrisis/p36419\#!/. Date visited: 9 December 2016.

Drysdale P. (2014). Put up or shut up on China's infrastructure bank. East Asia Forum, 22 September.

Hawkins A., Rahman J. and Williamson T. (2014). Is the global financial safety net at a tipping point to fragmentation? The Australian Treasury, Economic Roundup Issue 1, 2014.

Hoffman B. and Kuijs L. (2006). Rebalancing China's growth. Peterson Institute for International Economics, 2006.

Huang Y. (2016). Understanding China’s Belt \& Road Initiatives: motivation, framework and assessment. China Economic Review, Vol. 30, September 2016, pp. 314-321.

Huang Y., Dang W. \& Wang J. (2011). Reform of the international economic system: what does China want? In: Rising China: Global Challenges and Opportunities. Jane Golley and Ligang Song (eds), ANU Press, Canberra, pp. 29-44. 
International Monetary Fund (IMF) (2011). Analytics of Systemic Crises and the Role of Global Financial Safety Nets. International Monetary Fund, Strategy, Policy, and Review Department, 31 May, Washington DC.

International Monetary Fund (IMF) (2016a). Adequacy of the global financial safety net. International Monetary Fund, March 2016, Washington DC.

International Monetary Fund (IMF) (2016b). IMF World Economic Outlook (WEO). April 2016, Washington DC.

King M. (2016). The end of alchemy: Money, banking and the future of the global economy. Little Brown, Great Britain, 2016.

Lagarde C. (2016). The Role of Emerging Markets in a New Global Partnership for Growth. Managing Director speech. International Monetary Fund, University of Maryland, 4 February.

Lustig N. (1995). The Mexican Peso Crisis: The Foreseeable and the Surprise. Brookings Institution, Washington DC. June.

Montiel P. (2014). Ten crises. Routledge, New York, 2014.

Obstfeld M. and Rogoff K. (2009). Global imbalances and the financial crisis: Products of common causes. Federal Reserve Bank of San Francisco Asia Economic Policy

Conference, Santa Barbara, CA, October 18-20.

Overholt W. H., Ma G. and Law G.K. (2016). Renminbi rising: A New global monetary system emerges. Fung Global Institute Limited, John Wiley and Sons, United Kingdom.

Pitakdumrongkit K. (2015). Where to now for the Chiang Mai Initiative

Multilateralisation? East Asia Forum, 28 August.

Sester B. (2016). The return of the East Asian Savings Glut. Council on Foreign Relations Discussion Paper, October 2016.

Sterland B. (2013). Priorities for Australia's presidency of the G20 in 2014 and the role of the global financial safety net. Speech at the Shilla, Seoul, Republic of Korea, 19

December.

Truman E. (2014). IMF reform is waiting on the United States, Peterson Institute for International Economics. Paper no. PB14-9.

Truman E. (2013). Asian and European Financial Crises Compared. Peterson Institute for International Economics, Working Paper 13-9, October, Washington DC.

Xi J. (2015). G20 summit 2016, China. Beijing, 1 December. 
Xinhua (2015). China Focus: Xi Stresses Implementing Central Economic Policies. Xinhua, 9 July.

Yi G. (2011). Reform of the international monetary system, Lecture delivered at Peking University, 3 May 2011, Beijing.

Zhang D. (2016). The Making and Implementation of the Belt and Road (B\&R) Policy. EABER Working Paper, December. 